\title{
Otolith chemistry of juvenile snapper Pagrus auratus in Victorian waters: natural chemical tags and their temporal variation
}

\author{
Paul A. Hamer ${ }^{1,2, *}$, Gregory P. Jenkins ${ }^{1,2}$, Bronwyn M. Gillanders ${ }^{3}$ \\ ${ }^{1}$ Department of Primary Industries, PO Box 114, Queenscliff, Victoria 3225, Australia \\ ${ }^{2}$ Department of Zoology, University of Melbourne, Parkville, Victoria 3052, Australia \\ ${ }^{3}$ Southern Seas Ecology Laboratories, School of Earth and Environmental Sciences, The University of Adelaide, \\ Adelaide, South Australia 5005, Australia
}

\begin{abstract}
Determining contributions of juveniles from different areas to adult populations is difficult using traditional methods such as manual tagging and recapture. Environmental variation can, however, produce natural chemical tags in the otoliths of juvenile fish. Spatial variation in the otolith chemistry $(\mathrm{Ba}, \mathrm{Sr}, \mathrm{Mn})$ of age 0+ snapper collected from inlets along the coast of Victoria, southeastern Australia, enabled characterisation of otolith chemical tags for specific areas. In particular, a tag based largely on high Ba levels was specific to snapper from the largest juvenile area and most important fishery, Port Phillip Bay. This tag enabled accurate discrimination between snapper from this bay (98 and $85 \%$ ) and other Victorian nursery areas in the 2000 and 2001 year classes, respectively. Differences in classification accuracy between these year classes were due to lower Ba levels in otoliths from some sites within Port Phillip Bay in 2001. Variation in otolith chemical tags between adjacent sampling months during the recruitment period, although significant, did not confound spatial discrimination between Port Phillip Bay and other inlets. Likewise, variation in otolith chemical tags between adjacent year classes, while greater than between months, did not greatly confound spatial discrimination. Comparisons across 5 year classes over a 9 yr period for Port Phillip Bay, however, showed substantial differences in the elemental tag for this Bay. Differences in otolith chemistry between year classes were driven by variation in Ba and $\mathrm{Sr}$ levels, whereas between-month differences were due to Mn variation. Future classifications of adults to juvenile nursery areas will require chemical tags characterised from juveniles of the same year class(es) as the adults being classified. Small-scale (mo) temporal mismatches between the sampling of juvenile and adult otoliths of the same year class should not influence the accuracy with which adults are classified to juvenile origins.
\end{abstract}

KEY WORDS: Otolith chemistry $\cdot$ Natural tag $\cdot$ Temporal variation $\cdot$ Barium $\cdot$ Pagrus auratus $\cdot$ Laser Ablation ICP-MS

Resale or republication not permitted without written consent of the publisher

\section{INTRODUCTION}

For many species of marine fish, the distribution of adults is continuous, whereas the distribution of small juveniles is restricted to specific areas or habitats. Determining the contributions of different juvenile areas to the greater adult population is important for understanding population dynamics, the identification and protection of critical juvenile nursery areas, and the sustainable management of fisheries. Traditional tagging methodologies have generally failed to provide this information due to difficulties in manual tagging of large numbers of small juveniles, high mortality of the juvenile stages, low recapture rates, and biases in tagging and recapture effort. Study of the elemental composition of fish otoliths has demonstrated that incorporation of various elements into these predominantly calcium carbonate structures can poten- 
tially provide a mechanism for natural tagging of fish (Campana 1999, Campana \& Thorrold 2001).

Due to their metabolic inertness, continuous growth and incorporation of certain elements at rates that may be influenced by variation in environmental parameters (i.e. temperature, salinity, ambient concentration), otoliths can provide insights into the environmental history of fish (Campana 1999). Variation in otolith chemistry has been used to investigate stock structure (Edmonds et al. 1989, 1991, 1992, 1999, Campana \& Gagne 1995, Kalish et al. 1996, Thresher 1999), migration behaviour (Secor 1992, Secor et al. 1995, Tzeng et al. 1997, Secor \& Rooker 2000, Limburg et al. 2001), and larval dispersal (Swearer et al. 1999). Recent research has taken advantage of spatial variability in otolith chemistry to characterise chemical tags or signatures in otoliths of juvenile fish that are specific to certain areas (Gillanders \& Kingsford 1996, 2000, Milton et al. 1997, Thorrold et al. 1998a,b, Rooker et al. 2001a, Gillanders 2002a). Using finescale sampling techniques, such as laser ablation, to target the otolith region deposited during the juvenile phase within adult otoliths, several studies have now gone on to retrospectively determine the nursery origins of adults (Gillanders \& Kingsford 1996, Thorrold et al. 2001, Gillanders 2002b). This work has highlighted the potential for otolith chemistry to provide unprecedented information on the connectivity between juvenile habitats and adult populations.

The application of otolith chemistry as a natural tagging method depends firstly on finding spatial variation at the relevant scales. However, once this has been demonstrated, the knowledge of temporal variation in chemical tags, at a range of scales, is critical to determining how tags are used in retrospective determinations of adult origins (Gillanders 2002a). Variation in juvenile otolith chemistry has been found both between year classes (Milton et al. 1997, Rooker et al. 2001a, Gillanders \& Kingsford 2000, Gillanders 2002a), and between months within a year class (Thorrold et al. 1998a, Thorrold \& Shuttleworth 2000, Swearer et al. 2003). If temporal variation at either of these scales can confound spatial discrimination, then it will have major implications for the use of otolith chemical tags to retrospectively determine adult origins (i.e. Gillanders 2002a).

Snapper Pagrus auratus (Sparidae) are an ideal candidate for the application of otolith chemistry to investigate connectivity between the adult and juvenile life stages. The life history of snapper generally consists of a post-settlement and early juvenile phase within sheltered bays and estuaries, followed by migration of older juveniles (usually greater $1 \mathrm{yr}$ old) and sub-adults into coastal waters (Coutin et al. 2003). Snapper support an important recreational and commercial fishery in Victoria; however, the fishery is largely based in one bay: Port Phillip. Greater that $80 \%$ of the snapper catch comes from this bay alone (Anonymous 2002), and consequently management is strongly focussed on the dynamics of the fishery within Port Phillip Bay. Snapper recruit to the fishery in Victoria at 3 to $4 \mathrm{yr}$ of age ( $27 \mathrm{~cm}$ total length [TL]). Extensive migration of both adult ( $>4 \mathrm{yr}$ age) and sub-adult snapper between the ocean and Port Phillip Bay occurs (Coutin et al. 2003), although the dynamics of migration and the relationship between age and migration behaviour is poorly understood.

Spawning of snapper occurs during summer (November to February) both within Port Phillip Bay and in ocean waters, (Coutin et al. 2003). Larval settlement is generally completed by late March, with the bulk of settlement occurring from mid-December to February (P. A. Hamer unpubl. data). Port Phillip Bay provides the largest known nursery area for age $0+$ snapper (hereafter referred to as ' $0+$ snapper') in Victoria; however, numerous other smaller inlets and estuaries along the coast also provide nursery areas for $0+$ snapper. These other inlets and estuaries are small, in area, on an individual basis compared to Port Phillip Bay, and densities of $0+$ snapper within them are similar-to or less-than those in Port Phillip Bay (P. A. Hamer unpubl. data). Individually, the contribution of these estuaries to adult populations is likely to be small; however, as a group their contribution to adult stocks may be of considerable importance.

We have no understanding of the relative contributions of Port Phillip Bay and the other smaller nurseries to the adult fishery in Victorian waters, and, in particular to the fishery in Port Phillip Bay. This greatly inhibits attempts to understand population dynamics of snapper in Victoria. Recruitment of 0+ snapper into Port Phillip Bay is extremely variable from year to year (Coutin et al. 2003, P. A. Hamer unpubl. data). The importance of this variability to predicting the population dynamics of snapper in Victoria depends on quantifying connectivity between this nursery and the adult population.

This study is the initial step in our attempt to quantify the contributions of the various juvenile areas to adult stocks of snapper in Victorian waters. Of particular importance to this ongoing work is determining the degree to which Port Phillip Bay is self-recruiting. Our aim in this study is to firstly determine whether nursery-specific chemical tags can be identified in 0+ snapper otoliths, and secondly, to assess both long- and short-term temporal variation in tag composition, and the implications of this to their use in retrospective determination of adult origins. We compare otolith chemistry of $0+$ snapper between Port Phillip Bay and numerous bay, inlet and estuarine nursery areas both 
between months during the $0+$ recruitment period and between 2 adjacent year classes. We also investigate the long-term stability of 0+ otolith tags for Port Phillip Bay snapper by comparing otolith chemistry of $0+$ snapper across 5 year classes separated over a $9 \mathrm{yr}$ period.

\section{MATERIALS AND METHODS}

Field sampling and otolith analysis. Fish collections: $0+$ snapper ( $<5$ mo old) were sampled from the 2000 and 2001 year classes on 2 occasions, separated by ca. $1 \mathrm{mo}$, during late summer/early autumn (February/ March) of each year. Recruitment of 0+ snapper occurred in at least 6 bays, inlets and estuaries along the Victorian coast (Fig. 1). For simplicity we use the term 'inlet' to describe all areas. The 6 inlets we sampled were: Port Phillip Bay (PPB), Western Port Bay (WP), Corner Inlet (CIN), Gippsland Lakes (GL), Snowy River (S) estuary and Mallacoota Inlet (M) (Fig. 1). Samples were only obtained from the Snowy Estuary in 2001. Several other small estuaries along the east coast of Victoria were closed to the sea by sandbars during summer/autumn 2000 and 2001 and so no recruitment occurred. We currently have no evidence for recruitment of $0+$ snapper in coastal waters outside of bays and inlets. We did conduct several sampling trips to coastal locations, but failed to find 0+ snapper.

Within each inlet we collected snapper from multiple sites. The number of sites varied with size of the inlet, from 9 in Port Phillip Bay, to 2 in the Snowy Estuary (see Table 1). In the deeper inlets, such as Port Phillip Bay, Corner Inlet, Gippsland Lakes and Western Port Bay, we sampled with a small plumb-staff beam trawl modified from Gunderson \& Ellis (1986) and previously trialed for sampling 0+ snapper (Hamer et al. 1998). We sampled with this trawl at night to maximise capture efficiency (Hamer et al. 1998). The trawl had a fixed $3 \mathrm{~m}$ mouth width, $1.3 \mathrm{~m}$ mouth depth, $8 \mathrm{~mm}$ aperture mesh in the body, and $3 \mathrm{~mm}$ aperture mesh in the codend (see Hamer et al. 1998). In the Snowy Estuary and Mallacoota Inlet, we used a $10 \times 2 \mathrm{~m}, 1 \mathrm{~mm}^{2}$-mesh seine net fitted with $10 \mathrm{~m}$ hauling ropes. To minimise any school-related biases, recruits used in microchemical analysis were haphazardly selected from multiple randomly placed hauls of the seine, or trawls of the beam trawl, within each site.

Future use of chemical tags to classify adults will involve a random sample of the adult year class, and not a random sample of adults that came from the same settlement cohort. For this reason we chose not to restrict chemical analyses to fish of the same size or otolith weight, as this could introduce possible cohort related biases to tag characterisation (see 'Discussion'). Sampling fish on one particular occasion also introduces the possibility that short-term temporal variation in otolith chemistry could result in a tag that requires highly accurate temporal matching between sampling

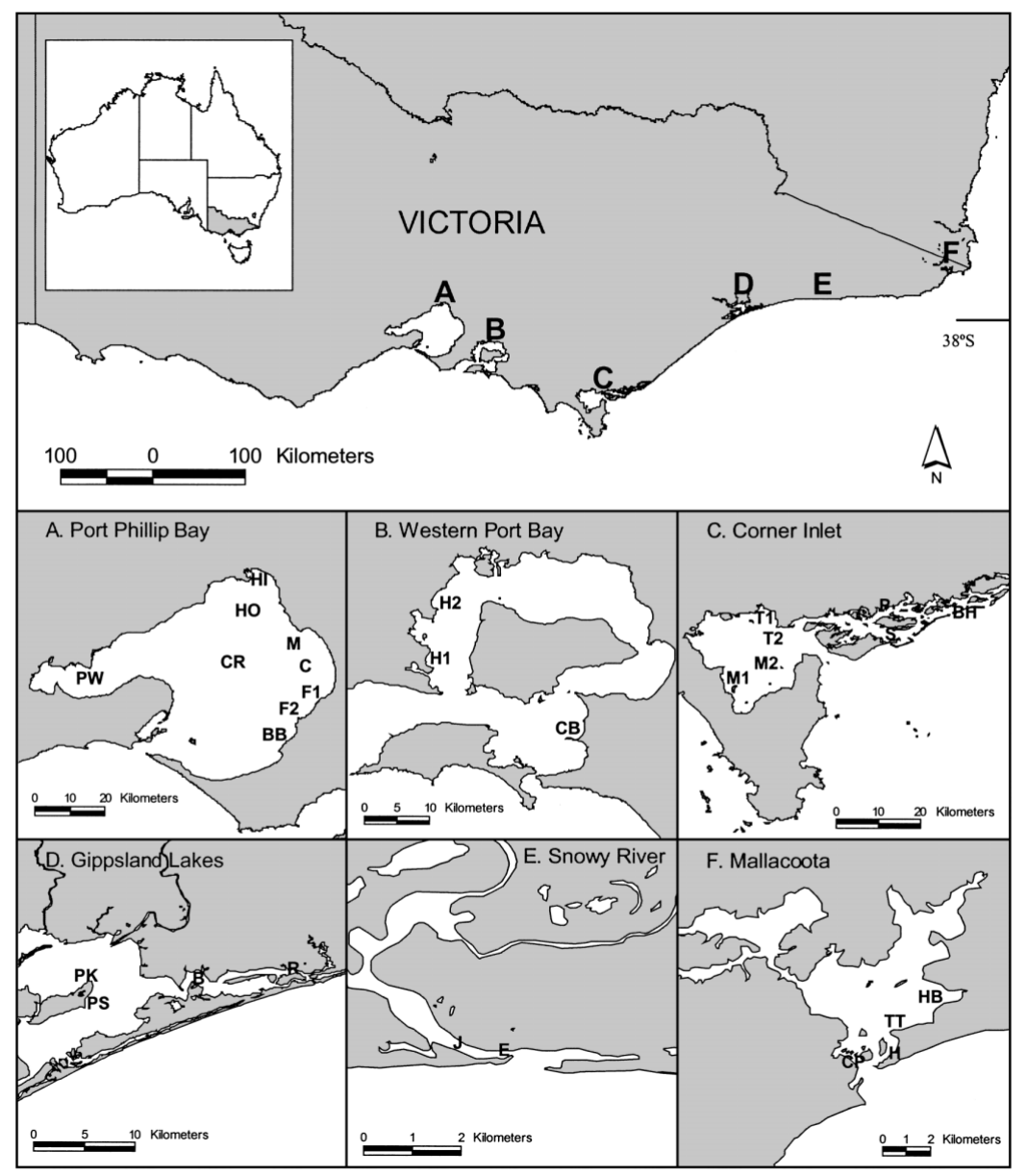

Fig. 1. Map of Australia (inset) and the Victorian coast, showing location of inlets where Pagrus auratus samples were collected (A to F) and sites within inlets, indicated by letter labels. $\mathrm{PW}=$ Point Wilson, $\mathrm{HI}=$ Hobsons Bay inner, $\mathrm{HO}=$ Hobsons Bay outer, $\mathrm{CR}=$ Central, $\mathrm{M}=$ Mordialloc, $\mathrm{C}=$ Carrum, $\mathrm{F} 1=$ Frankston 1, F2 = Frankston 2, BB = Balcombe Bay, H1 = Hastings 1, $\mathrm{H} 2=$ Hastings $2, \mathrm{CB}=$ Coronet Bay, $\mathrm{T} 1=$ Toora Channel $1, \mathrm{~T} 2=$ Toora Channel 2, M1 = Middle Channel 1, M2 = Middle Channel 2, $\mathrm{P}=$ Pelican, $\mathrm{S}=$ Snake $\mathrm{BH}=$ Boat Harbour, PK, Point King, PS = Point Scott, B = Bancroft Bay, $\mathrm{R}=$ Reeves Channel, $\mathrm{J}=$ Jetty, $\mathrm{E}=$ Entrance, $\mathrm{CP}=$ Caravan Park, $\mathrm{H}=$ Harrison's, $\mathrm{TT}=$ Tea Tree, $\mathrm{HB}=$ Howe Bight 
Table 1. Pagrus auratus. Details of the sizes and otolith weights of 0+ age snapper analysed for otolith chemistry from various inlets along the Victorian coast. Temperature and salinity were measured at the same sites and times as fish were collected and are averaged across sites within each inlet. $\mathrm{SL}=$ standard length, $\mathrm{OW}=$ otolith weight, $\mathrm{T}=$ temperature, $\mathrm{S}=$ salinity

\begin{tabular}{|c|c|c|c|c|c|c|c|}
\hline $\begin{array}{l}\text { Year Class } \\
\text { Inlet }\end{array}$ & Month & $\begin{array}{l}\text { Sites } \\
(\mathrm{N})\end{array}$ & $\begin{array}{l}\text { Fish } \\
(\mathrm{N})\end{array}$ & $\begin{array}{cc}\mathrm{SL} & \text { Mean } \\
\mathrm{mm} & \text { (range) }\end{array}$ & $\begin{array}{cc}\text { OW } & \text { Mean } \\
\text { mg } & \text { (range) }\end{array}$ & $\mathrm{T}\left({ }^{\circ} \mathrm{C}\right)$ & $S(p p t)$ \\
\hline \multicolumn{8}{|l|}{2000} \\
\hline \multirow[t]{2}{*}{ Port Phillip Bay } & February & 4 & 14 & $32.04(23-61)$ & $1.25(0.4-4.9)$ & 20.5 & 36.5 \\
\hline & March & 5 & 26 & $53.94(30-74)$ & $4.10(1.4-8.0)$ & 18.7 & 37.0 \\
\hline Western Port Bay & February & 1 & 2 & $17.50(15-20)$ & $0.25(0.2-0.3)$ & 22.1 & 37.0 \\
\hline \multirow{2}{*}{ Corner Inlet } & February & 2 & 16 & $31.44(16-53)$ & $1.34(0.2-3.4)$ & 21.1 & 37.2 \\
\hline & March & 5 & 24 & $46.34(20-75)$ & $2.95(0.5-7.3)$ & 18.5 & 37.6 \\
\hline \multirow[t]{2}{*}{ Gippsland Lakes } & February & 3 & 13 & $30.54(21-39)$ & $0.93(0.3-1.6)$ & 21.4 & 32.4 \\
\hline & March & 4 & 22 & $56.54(39-79)$ & $4.35(1.9-7.9)$ & 19.4 & 31.2 \\
\hline Mallacoota Inlet & March & 2 & 20 & $40.97(29-56)$ & $2.70(0.3-1.6)$ & 24.0 & 34.4 \\
\hline \multicolumn{8}{|l|}{2001} \\
\hline \multirow[t]{2}{*}{ Port Phillip Bay } & February & 8 & 53 & $55.27(15-82)$ & $4.28(0.5-8.5)$ & 22.4 & 36.7 \\
\hline & March & 9 & 56 & $64.09(27-100)$ & $7.37(1.0-17.6)$ & 18.7 & 36.5 \\
\hline Western Port Bay & March & 2 & 4 & $44.75(25-47)$ & $3.23(0.9-5.0)$ & 16.7 & 37.0 \\
\hline \multirow[t]{2}{*}{ Corner Inlet } & February & 6 & 39 & $38.02(15-68)$ & $1.83(0.2-5.5)$ & 20.1 & 36.5 \\
\hline & March & 6 & 25 & $54.72(21-94)$ & $5.19(0.4-13)$ & 16.5 & 36.8 \\
\hline \multirow[t]{2}{*}{ Gippsland Lakes } & February & 2 & 13 & $40.92(23-60)$ & $2.21(0.4-4.2)$ & 21.2 & 31.7 \\
\hline & March & 2 & 14 & $53.58(26-93)$ & $5.39(0.8-13.6)$ & 18.0 & 28.8 \\
\hline \multirow[t]{2}{*}{ Snowy Estuary } & February & 1 & 6 & $34.80(25-42)$ & $1.27(0.6-1.8)$ & 21.8 & 30.8 \\
\hline & March & 2 & 10 & $52.50(22-74)$ & $4.41(0.5-8.0)$ & 18.1 & 32.9 \\
\hline \multirow[t]{2}{*}{ Mallacoota Inlet } & February & 3 & 15 & $53.20(28-90)$ & $4.97(0.9-15.9)$ & 22.9 & 27.5 \\
\hline & March & 4 & 16 & $51.95(17-100)$ & $5.37(0.5-20.5)$ & 21.8 & 29.8 \\
\hline
\end{tabular}

of juvenile and adult otoliths (see 'Discussion'). We chose to haphazardly sample fish from the entire population of $0+$ recruits in different months towards the end of the larval settlement period. This would produce a tag more representative of the population of $0+$ recruits and allow us to also assess the potential for short-term variations to influence tag composition.

We investigated longer-term (>5 yr) between yearclass variation for Port Phillip Bay 0+ snapper, by comparing archived otolith samples collected in the 1993, 1995, and 1996 year classes with those from the 2000 and 2001 year classes. Two long-term comparisons were made; the first involved 0+ recruits from the 1995 and 2001 year classes collected from the same 6 sites (Fig. 1: PW, HI, HO, M, CR, BB). The second involved 0+ recruits from 2 sites (Fig. 1: HI, M) compared over 5 year classes (1993, 1995, 1996, 2000 and 2001). Collection times for the archived samples were similar to those for the 2000 and 2001 year classes. Archived samples were collected by otter trawl as part of an ongoing ecosystem monitoring program in Port Phillip Bay (for sampling methodology see Hobday et al. 1999).

Otolith preparation: The sagittal otoliths were generally dissected from chilled fish on return from the field; however, we received some frozen specimens from fishermen. Otoliths in the archived samples were dissected from fish that had been refrigerated for periods of up to $10 \mathrm{~h}$. Comparison between freshly dissected (chilled for $8 \mathrm{~h}$ ) and frozen (frozen for $80 \mathrm{~d}$ ) otoliths showed no effect of freezing on the concentra- tions of $\mathrm{Mn}, \mathrm{Sr}$, and Ba near the edges of otoliths ( $t$-test, df $10, p>0.05$ for each element). Other studies have similarly shown no difference between $\mathrm{Ba}, \mathrm{Sr}$ and $\mathrm{Mn}$ concentrations in otoliths that were either dissected when fresh, or after being frozen (Rooker et al. 2001b). Otoliths were cleaned of adhering tissue in Milli-Q water, air dried for at least $24 \mathrm{~h}$, and stored in plastic vials until mounting.

Otoliths were weighed to the nearest $0.1 \mathrm{mg}$ prior to mounting in epoxy resin (Struers epofix). Transverse sections of approximately $350 \mu \mathrm{m}$ thickness were taken through the primordium using a continuous flow of Milli-Q water to lubricate the diamond blade. Sections where polished with 3 grades of aluminium oxide lapping film $(30,9,3 \mu \mathrm{m})$ lubricated with Milli-Q water. The polished sections were fixed to acid-cleaned $\left(10 \% \mathrm{HNO}_{3}\right)$ microscope slides with indium (In) doped epofix resin. We doped the epoxy resin used for mounting and fixing with approximately $30 \mathrm{ppm}$ In as a resin indicator. Final cleaning involved a $3 \mathrm{~min}$ immersion in Milli-Q water in an Ultrasonic bath, followed by a final triple rinse with Milli-Q water and drying inside a Class 100 plastic laminar flow cabinet. Pre-ablation was also used to eliminate any chance that surface contamination might influence results.

Otolith analyses: Otoliths were analysed with a Merchantek LUV 266 ${ }^{\mathrm{TM}} \mathrm{Nd}$ :YAG ultraviolet laser microprobe operated in Q-switched mode in conjunction with a Finnigan MAT ELEMENTTM high resolution inductively coupled plasma double-focusing mass 
spectrometer (HR-ICP-MS). Ablation was conducted in helium that was mixed with argon for transport to the plasma and subsequent analysis in the mass spectrometer. A more detailed description of the system used in this study is provided in Lahaye et al. (1997). Operating conditions of the laser and HR-ICP-MS are outlined in Table 2. After a preliminary investigation, we decided to focus on the isotopes ${ }^{55} \mathrm{Mn},{ }^{88} \mathrm{Sr}$, and ${ }^{138} \mathrm{Ba}$, along with ${ }^{44} \mathrm{Ca}$ which was used as the internal standard and ${ }^{115} \mathrm{In}$, the resin indicator.

We chose to sample near the edge of otoliths to represent the most recent period of elemental incorporation, as this is most relevant to the site of capture. We made 3 ablations of 90 to $100 \mu \mathrm{m}$ on each otolith. Each ablation sampled ca. 15 to $20 \mathrm{~d}$ of otolith growth. The 3 ablations were situated 1 near the dorsal tip, 1 near the ventral tip, and 1 near the ventral side of the sulcal groove. Variation within otoliths for all elements was less than between otoliths. From ANOVA of a preliminary sample of 30 otoliths from 2 randomly selected inlets the \% variation explained among/ within otoliths was: Mn 58/42\%, Sr 67/33\%, Ba 91/9\%. The high variation within otoliths for Mn was due to a consistent difference between the spot adjacent to the sulcal groove (i.e. lower values) and the spots at the dorsal and ventral tip areas (i.e. similar and higher values). Standardisation of sampling locations within otoliths has been previously suggested to account for the possibility of consistent within-otolith variations (Campana 1999). We therefore analysed all otoliths in similar areas, and averaged data from the 3 ablations to provide the elemental concentrations used in statistical analysis.

Table 2. Details of the laser and HR-ICP-MS operating parameters used in the study

\begin{tabular}{ll}
\hline Laser & \\
Wavelength & $266 \mathrm{~nm}$ \\
Mode & Q switched \\
Repetition rate & $6 \mathrm{~Hz}$ \\
$\begin{array}{l}\text { Energy } \\
\text { Spot size }\end{array}$ & $0.9-1 \mathrm{~mJ}$ \\
Mixing chamber & $90-100 \mu \mathrm{m}$ \\
HR-ICP-MS & He $\left(0.361 \mathrm{~min}^{-1}\right)$ \\
\hline Resolution & \\
Gas flow & 300 \\
Coolant & \\
Auxilliary & $14.001 \mathrm{~min}^{-1}$ \\
Sample & $1.551 \mathrm{~min}^{-1}$ \\
Cone & $1.501 \mathrm{~min}^{-1}$ \\
Detection modes & Nickel \\
& Analogue $(\mathrm{Ca}, \mathrm{Sr})$ \\
& Pulse counting $(\mathrm{Mn})$ \\
Dwell time & Both $(\mathrm{Ba})$ \\
Channels/peak & $10 \mathrm{~ms}$ \\
Magnet settling time & $3(22 \%$ of mass window) \\
& $1 \mathrm{~ms}$ per amu $+5 \mathrm{~ms}$ \\
\end{tabular}

To eliminate the possibility of biases due to instrument drift, we randomised and blocked the analysis sequence with respect to inlet. At the time of this study, no certified otolith-based standard that was suitable for laser analysis was available. We used the NIST SRM 612 glass standard for quantification of elemental concentrations. We analysed this standard every 10 to 12 ablations to further eliminate possible short-term drift effects. The concentration of $\mathrm{Ca}$ in otoliths was taken as $38.8 \%$ by weight or $388000 \mathrm{ppm}$ following the determination of otolith $\mathrm{Ca}$ concentration presented in Yoshinaga et al. (2000). The average counts of a 20 -scan blank acquired prior to each ablation were subtracted from the average sample counts before concentration calculations. Samples were acquired for 50 scans (approx. 30 s), with the initial 10 scans being ignored to allow for pre-ablation and signal stabilisation. The ablation cell was purged for $20 \mathrm{~s}$ prior to each blank/sample acquisition. Data reduction was conducted offline. If indium spikes occurred in the data, we removed the associated scans prior to averaging of counts. We found that indium counts were rarely above background and indium spikes were generally associated with the laser ablating through the sample. We converted raw data (counts $\mathrm{s}^{-1}$ ) to concentrations $\left(\mu \mathrm{g} \mathrm{g}^{-1}\right)$ using the equation of Ludden et al. (1995):

$$
\left(C_{X}\right)_{\mathrm{samp}}=\frac{\left(I_{\mathrm{m}, \mathrm{X}} / I_{\mathrm{m}, \mathrm{Is}}\right)_{\mathrm{samp}} \times\left(C_{\mathrm{Is}}\right)_{\mathrm{samp}} \times\left(C_{\mathrm{m}, \mathrm{X}}\right)_{\mathrm{std}}}{\left(I_{\mathrm{m}, \mathrm{X}} / I_{\mathrm{m}, \mathrm{Is}}\right)_{\mathrm{std}} \times\left(C_{\mathrm{Is}}\right)_{\mathrm{std}}}
$$

where: $C_{X}=$ concentration of element being quantified; $I_{\mathrm{m}, \mathrm{x}}=$ intensity at mass $\mathrm{x}$ of the element being quantified $I_{\mathrm{m}, \mathrm{Is}}=$ intensity at the mass used for the internal standard; $C_{\mathrm{IS}}=$ concentration of the internal standard element; Std $=$ Standard $;$ samp $=$ sample. A blank of 70 scans was acquired at the start and end of each session. We used the standard deviation of these blanks in calculations of detection limits. Detection limits depend on the amount of material ablated, and were therefore adjusted for each ablation based on ablationyield estimates. Average detection limits $\left(\mu \mathrm{g} \mathrm{g}^{-1}\right)$ were, ${ }^{55} \mathrm{Mn}: 0.32,{ }^{88} \mathrm{Sr}: 0.39,{ }^{138} \mathrm{Ba}: 0.02,{ }^{115} \mathrm{In}: 0.015$.

Both accuracy and precision were estimated on a daily basis for the NIST SRM 612 and precision was also estimated for a pressed pellet made of ground snapper otolith. Precision estimates for individual elements, measured as the mean relative standard deviation (RSD) in 2000/2001 for the NIST SRM 612 were: Mn $10 / 4 \%$, Sr 5/2\%, Ba 5/3\%. Precision estimates for the pressed pellet in 2000/2001 were: Mn 25.3/19\%, Sr 4.5/3.9\%, Ba 7.0/5.1\%. Accuracy for individual elements measured as mean percentage recovery for the NIST SRM 612 in 2000/2001 were: Mn 97.2/100.2\%, Sr 99.2/100\%, Ba 98.8/100\%. 
As our external standard was not matrix matched, we decided to further check precision between analyses performed in different years. In 2001 we re-analysed otoliths of 25 haphazardly selected fish analysed in 2000 by ablations immediately adjacent to those from 2000. Replicated analyses showed no significant differences in $\mathrm{Ba}$ and $\mathrm{Sr}$ determinations between the 2 years ( $t$-test, $\mathrm{df}=23, \mathrm{p}>0.05)$. There was a small but significant difference in $\mathrm{Mn}$ determinations between years ( $t$-test, $\mathrm{df}=23, \mathrm{p}=0.031$ ), with slightly higher Mn concentrations (mean difference $=0.896 \mathrm{\mu g} \mathrm{g}^{-1}$ ) in 2000 than 2001. Interannual comparisons for $\mathrm{Ba}$ and $\mathrm{Sr}$ should not be influenced by any systematic differences in instrument performance between years. For interannual comparisons, we elected to adjust data for $\mathrm{Mn}$ by subtraction of $0.896 \mu \mathrm{g} \mathrm{g}^{-1}$ (mean difference) from the determinations for each otolith analysed in 2000.

Statistical methods. Individual elements: Univariate ANOVA was used to test hypotheses relating to temporal and spatial variation in concentrations of individual elements in 0+ snapper otoliths. We performed several ANOVA to investigate variation in levels of elements between otoliths of fish sampled a month apart in 2000 and 2001, and between these 2 year classes. Due to a lack of samples from a number of sites, and one inlet in particular during the first month of sampling in 2000, we restricted the between adjacent-year-class comparison to the second sampling month (March) of each year. We could only sample Mallacoota Inlet in the second month of 2000, so it is not included in the month comparison for 2000 but is displayed graphically. Otolith chemistry data were averaged across fish from each net haul within each site. Western Port Bay was not included in any univariate analyses due to the low number of samples, but is displayed graphically. For longer-term between yearclass comparisons involving only Port Phillip Bay, we performed 2 separate ANOVAs (i.e. 6 sites across 2 year classes and 2 sites across 5 year classes). Inlet, month and year were treated as fixed factors in all ANOVA. For all analyses, data for $\mathrm{Ba}$ and $\mathrm{Mn}$ required $\ln (x+1)$ transformation to meet the assumption of homogeneity of variances. We did not make adjustments of significance levels to account for multiple analyses, although it would be expected that at $\alpha=$ 0.05, 1 in 20 tests would be significant by chance alone. Information on $\mathrm{p}$-values is included in the results to indicate the strength of significant results.

Multi-elemental tags: Multi-variate ANOVA (MANOVA) was used to investigate spatial differences in otolith multi-elemental tags. Quadratic discriminant function analysis (QDFA) was used to determine whether Port Phillip Bay 0+ snapper could be distinguished from those from all other inlets based on otolith composition. For these analyses, we grouped the data into 2 groups: samples from Port Phillip Bay and samples from all the other inlets. This grouping was in line with the main aim of separating Port Phillip Bay from all other nursery areas; however, grouping of the other inlets was also required to produce equality in sample size, which is important for discriminant function analysis (Quinn \& Keough 2002). QDFs and classification accuracies were determined for each year class and for the different months sampled within each year class. Classification accuracies were determined using the leave-one-out approach (i.e. the observation being classified is removed from the data set). F-to-remove statistics, which provide a measure of the contribution that individual variables make to discrimination, were used to assess which elements contributed most to discrimination power (Wilkinson et al. 1996). Canonical discriminant function plots of the data, with $95 \%$ confidence ellipses around the data for each group, were used to display temporal and spatial variation in the multi-elemental tags. To further examine the similarity in otolith signatures between the 2000 and 2001 year classes, we used 1 year class as a training set to classify the other year class being investigated. For all MANOVA and QDFA, Ba and Mn data were $\ln (x+1)$ transformed. While individual elements showed approximate univariate normality, examination of within-group scatterplot matrices suggested some deviation from the assumption of equality of covariance matrices. QDFA was chosen as opposed to linear discriminant function analysis as it does not require homogeneity of within-group covariance matrices (Quinn \& Keough 2002). The Pillai trace statistic was used to test for significance in MANOVA as it is the most robust to deviations from multivariate normality (Quinn \& Keough 2002).

\section{RESULTS}

\section{Fish size and otolith weight}

Differences in recruitment patterns among various inlets resulted in some differences in fish sizes and otolith weights (Table 1). Although size or age variation could potentially influence variation in otolith chemistry (i.e. Fowler et al. 1995, Bath et al. 2000), inclusion of otolith weight as a co-variate in a previous study of the same species and developmental stage made no difference to results of statistical analyses (Gillanders 2002a). We also found no evidence for relationships between otolith weight and elemental concentrations based on correlation analyses, and elected not to include the co-variate in our analysis. We also suggest that the application of co-variates in retrospective studies of adult origins is not appropriate or is 
indeed illogical, as an accurate determination of the co-variate (i.e. otolith weight) appropriate to the time of sampling of the adult otolith would be difficult.

\section{Individual elements}

Spatial variation

We found significant spatial variation in otolith elemental concentration both among inlets and among sites within inlets for $\mathrm{Ba}$ and $\mathrm{Mn}$ in 2001, and for $\mathrm{Ba}$ in 2000 (Table 3a, Fig. 2). Sr levels varied significantly between inlets only in 2001, but the month by inlet interaction was also significant (Table 3a, Fig. 2). The important result, in relation to finding an elemental tag unique to Port Phillip Bay, was that Ba was higher in Port Phillip Bay otoliths than those from all the other inlets in both years (Tukey's post hoc test, p < 0.001) (Fig. 2).

\section{Variation between adjacent months}

Mn showed a small but significant difference between months across all inlets in 2001 (Table 3a, Fig. 2). There was no significant difference in 2000, although fewer sites and inlets were included in this analysis (Table 3a, Fig. 2). In 2001, Mn concentrations were generally higher across all inlets in the first sam-

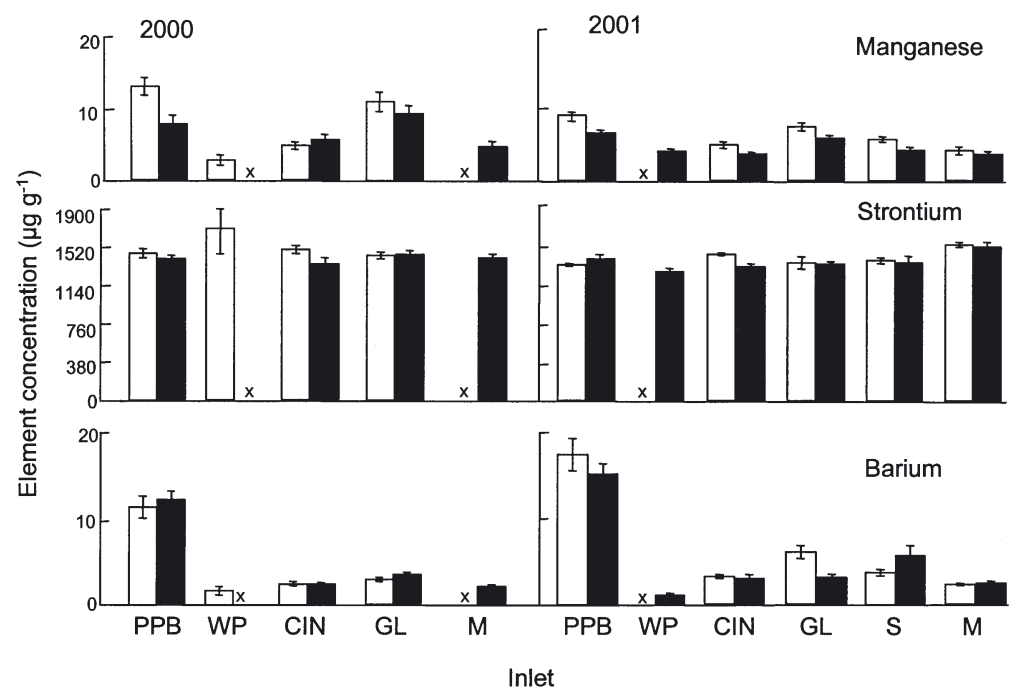

Fig. 2. Pagrus auratus. Mean concentrations $( \pm \mathrm{SE})$ of $\mathrm{Mn}, \mathrm{Sr}$ and $\mathrm{Ba}$ in $0+$ otoliths collected in 6 nursery areas along the Victorian coast in 2 adjacent months (February: open bars, March: dark bars) for 2 adjacent year classes (2000 and 2001). Data are pooled across sites within inlets, see Table 1 for details of fish numbers and number of sites sampled within inlets. x: no samples collected. PPB: Port Phillip Bay; WP: Western Port Bay; CIN: Corner Inlet; GL: Gippsland Lakes; M: Mallacoota Inlet; S: Snowy River estuary pling month (Fig. 2). In 2001 there were significant interactions between month and inlet for $\mathrm{Sr}$, and between month and site nested within inlet for $\mathrm{Ba}$ (Table 3a).

\section{Variation between adjacent year classes}

Differences between adjacent year classes were general across all inlets for Sr only (Table 3b). Sr levels were generally higher in otoliths from the 2000 year class than the 2001 year class (Fig. 2). There were no between-year effects or spatio-temporal interactions for Mn (Table 3b). There was, however, a strong year class-by site nested within inlet interaction for $\mathrm{Ba}$ (Table 3b).

\section{Long-term among-year-class variation for Port Phillip Bay}

Among-year-class variation in $0+$ otolith chemistry was significant over longer time scales for both $\mathrm{Ba}$ and Sr. These elements varied significantly among year classes in both the analysis involving 6 sites compared across 2 year classes (1995 and 2001) and 2 sites compared across 5 year classes (1993, 1995, 1996, 2000 and 2001) (Table 3b). Both Ba and Sr were generally higher in the 2000 and 2001 year classes than the other year classes (Fig. 3); however, Ba levels in 2000 were similar to 1993 (Fig. 3b). There were weak year-by-site interactions for Ba and $\mathrm{Mn}$ in the comparison involving 6 sites across 2 year classes, and a strong yearby-site interaction for $\mathrm{Ba}$ in the comparison involving 2 sites across 5 year classes (Table 3b).

\section{Multi-elemental tags \\ Spatial discrimination}

We found highly significant differences between the Port Phillip Bay elemental tag (Ba, Mn, Sr) and that of the other inlet group in both the 2000 and 2001 year classes (MANOVA, p < 0.001). Differences between Port Phillip Bay and the other inlets were also highly significant in both sampling months of each year class (MANOVA, p < 0.001). Overall accuracy of discrimination (QDFA) between Port Phillip Bay snapper and those from other inlets based on $\mathrm{Ba}, \mathrm{Sr}$ and Mn was high, at $99 \%$ for 2000 and 
Table 3. Pagrus auratus. Results of ANOVA for concentrations of elements in $0+$ otoliths compared within (a) and between (b) adjacent year classes sampled from Victorian inlets, and across 2 year classes at 6 sites and 5 year classes at 2 sites for Port Phillip Bay. Mn and Ba transformed to $\ln (x+1) .{ }^{* * *} \mathrm{p}<0.001$, ${ }^{* *} \mathrm{p}<0.01,{ }^{*} \mathrm{p}<0.05$

\begin{tabular}{|c|c|c|c|c|}
\hline Source & df & Ms Mn & Ms Sr & Ms Ba \\
\hline \multicolumn{5}{|c|}{ a) Within-year-class comparisons } \\
\hline \multicolumn{5}{|l|}{2000} \\
\hline Inlet & 2 & 0.232 & 1909 & $1.203^{* * *}$ \\
\hline Month & 1 & 0.145 & 27569 & 0.007 \\
\hline Month $\times$ Inlet & 2 & 0.027 & 2206 & 0.010 \\
\hline Site (Inlet) & 7 & 0.051 & 31968 & $0.031^{* *}$ \\
\hline Month $\times$ Site (Inlet) & 7 & 0.016 & 10582 & 0.008 \\
\hline Residual & 30 & 0.041 & 22328 & 0.007 \\
\hline \multicolumn{5}{|l|}{2001} \\
\hline Inlet & 4 & $1.504^{* *}$ & $26345^{*}$ & $12.051^{* *}$ \\
\hline Month & 1 & $0.413^{*}$ & 19227 & 0.072 \\
\hline Month $\times$ Inlet & 4 & 0.095 & $49290^{* * *}$ & 0.323 \\
\hline Site (Inlet) & 14 & $0.246^{* * *}$ & 6938 & $1.541^{* * *}$ \\
\hline Month × Site (Inlet) & 14 & 0.083 & 5189 & $0.162^{*}$ \\
\hline Residual & 63 & 0.066 & 5221 & 0.070 \\
\hline \multicolumn{5}{|c|}{ b) Between-year-class comparisons } \\
\hline \multicolumn{5}{|c|}{2000 and 2001 year classes all inlets } \\
\hline Inlet & 3 & 0.708 & 21366 & $10.281^{* * *}$ \\
\hline Year & 1 & 0.420 & $353877^{* * *}$ & 0.003 \\
\hline Year $\times$ Inlet & 3 & 0.076 & 21366 & 0.078 \\
\hline Site (Inlet) & 9 & 0.288 & 48169 & $0.323^{* * *}$ \\
\hline Year × Site (Inlet) & 9 & 0.241 & 14165 & $0.463^{* * *}$ \\
\hline Residual & 45 & 0.265 & 22760 & 0.073 \\
\hline \multicolumn{5}{|c|}{ Port Phillip Bay, 6 sites, 2001 and 1995 year classes } \\
\hline Site & 5 & $0.522^{*}$ & 6770 & $3.683^{* * *}$ \\
\hline Year & 1 & 0.108 & $443547^{* * *}$ & $28.060^{* * *}$ \\
\hline Year $\times$ site & 5 & $0.562^{*}$ & 4206 & $0.763^{*}$ \\
\hline Residual & 84 & 0.214 & 15977 & 0.240 \\
\hline \multicolumn{5}{|c|}{ Port Phillip Bay, 2 sites, 2001, 2000, 1996, 1995 and 1993 year classes } \\
\hline Site & 1 & 0.855 & 9381 & 3.394 \\
\hline Year & 4 & 0.625 & $233905^{* * *}$ & $31.308^{* * *}$ \\
\hline Year $\times$ site & 4 & 0.306 & 7820 & $2.256^{* * *}$ \\
\hline Residual & 81 & 0.291 & 18278 & 0.261 \\
\hline
\end{tabular}

Variation in multi-elemental tags between adjacent months

The Port Phillip Bay elemental tag varied significantly between February and March in both the 2000 and 2001 year classes (MANOVA, $p<0.001$ for 2000, p < 0.05 for 2001) (Fig. 4b). In both 2000 and 2001, Mn was the most important in driving differences between months (greatest F-to-remove value). For the other inlets group there was no significant difference in the elemental tag between months in 2000 (MANOVA, p > 0.05) (Fig. 4b); however, there was a significant difference found between months in 2001 (MANOVA, p < 0.001) (Fig. 4b). Mn was again the most important element in driving differences between months (largest F-to-remove value).

\section{Variation in multi-elemental tags between adjacent year classes}

For both Port Phillip Bay and the other inlets group, the elemental tags varied significantly between the 2000 and 2001 year classes (MANOVA, p < 0.001 for all tests) (Fig 4a). These differences were largely driven by differences in Sr levels between the 2 years (largest $F$-to-remove values for both tests).
$87.5 \%$ in 2001 (Table 4a). Ba made, by far, the greatest contribution to discrimination power in both year classes (F-to-remove statistics: 2000, Ba $=381.2, \mathrm{Sr}=$ 16.7, $\mathrm{Mn}=0.5 ; 2001, \mathrm{Ba}=189.14, \mathrm{Sr}=12.44, \mathrm{Mn}=$ 0.07). Canonical discriminant function plots show no overlap of the $95 \%$ confidence ellipses (representing the elemental tags) for the 2000 year class, but some overlap for the 2001 year class, both for data separated by months and data pooled across months (Fig. 4). The lower overall classification accuracy between Port Phillip Bay 0+ otoliths and those from the other nurseries in 2001 compared to 2000 was largely due to the site-within-inlet by year interaction for Ba (Table 3a). Closer inspection of the data revealed that most misclassifications were from 1 or 2 sites within Port Phillip Bay that had lower Ba levels in 2001 than 2000.

\section{Long-term among-year-class variation for Port Phillip Bay}

We found highly significant differences in the chemistry of 0+ otoliths from Port Phillip Bay among year classes. Differences were highly significant for both comparisons (MANOVA, $\mathrm{p}<0.001$ ). Separation of $95 \%$ confidence ellipses in the canonical variate plot was almost complete between 2000/2001 and 1996, indicating major differences in otolith chemistry. While 1995 and 1996 had considerable overlap, they only overlapped slightly with 2000, 2001 and 1993 (Fig. 5). For both comparisons, Ba was the most influential element in discrimination among year classes ( $F$-toremove, 6 sites for 1995, 2001: $\mathrm{Ba}=51.18, \mathrm{Mn}=16.53$, $\mathrm{Sr}=11.78$; F-to-remove, 2 sites for 1993, 1995, 1996, 2000, 2001: $\mathrm{Ba}=16.83, \mathrm{Sr}=9.94, \mathrm{Mn}=3.02$ ). 


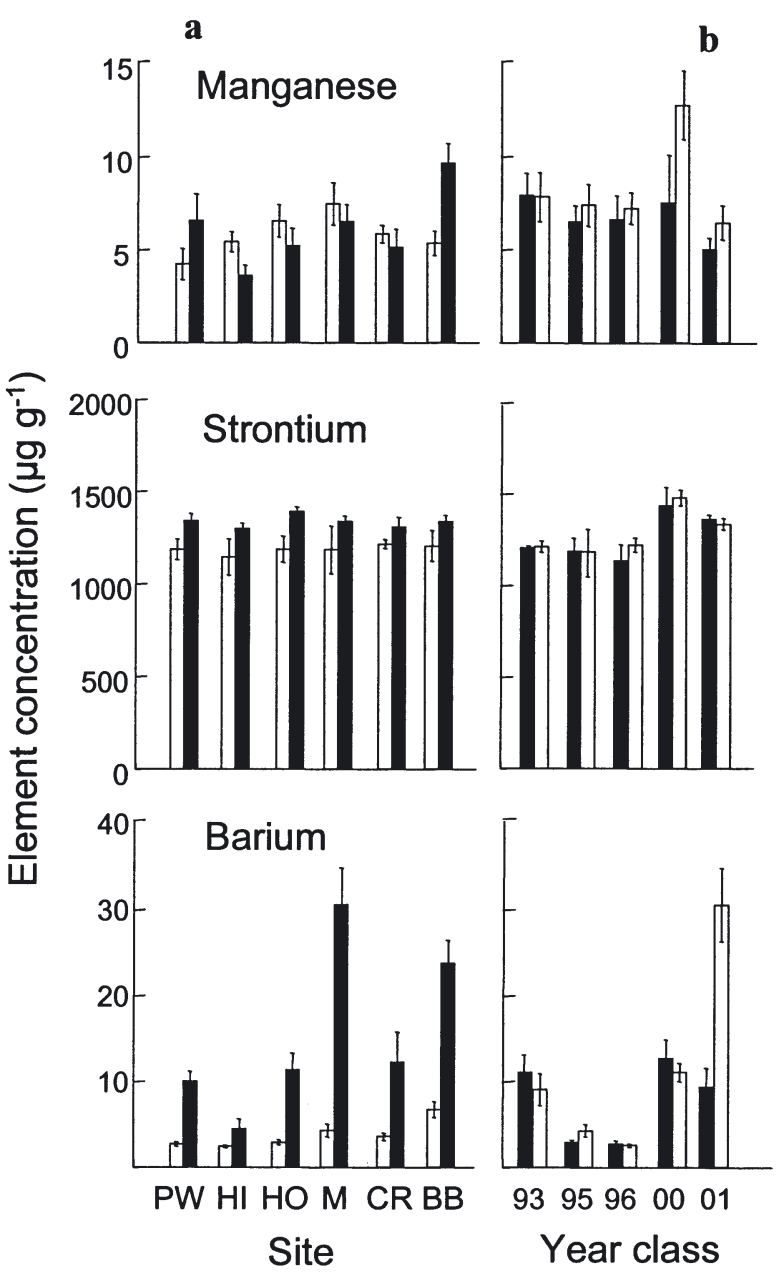

Fig. 3. Pagrus auratus. Mean $( \pm \mathrm{SE})$ concentrations of $\mathrm{Mn}, \mathrm{Sr}$, and $\mathrm{Ba}$ in 0+ otoliths collected at (a) 6 sites within Port Phillip Bay, and compared between 2 year classes (1995 open bars, 2001 dark bars) separated by 6 yr, and (b) 2 sites (HI dark bars, $M$ open bars) for 5 year classes separated across 9 yr. See Fig. 1 legend for site definitions ellipses for Port Phillip Bay and the other areas (Fig. 4). The canonical variate plots also show that separation between 95\% confidence ellipses for the different groups is maintained irrespective of which month or year is compared (Fig. 4). This means that short-term changes in elemental composition were not strong enough to confound spatial discrimination. The similarity of elemental composition between the 2000 and 2001 year classes is further demonstrated by the accuracy with which data from the 2000 year class classified 2001 fish and visa versa (i.e. 99 and 82\%, respectively) (Table 4b).

Unfortunately, we did not have otoliths from other areas to compare to Port Phillip Bay for the long-term among-year-class comparison. However, the differences in otolith composition among year classes for Port Phillip Bay 0+ snapper were large and primarily driven by $\mathrm{Ba}$, the major discriminatory element. This result implies that to have confidence in the classification of adults to nursery origins, it would be important to classify them based on juvenile tags characterised for the same year class.

\section{DISCUSSION}

Spatial variation in otolith multi-elemental composition (Mn, Sr, Ba) allowed accurate discrimination between 0+ age Pagrus auratus from Port Phillip Bay and those from other Victorian inlets in 2 adjacent year classes. The differences in otolith chemistry, particularly in Ba levels, provided the basis for a natural tag that identified Port Phillip Bay juveniles from those of other areas. Variations in tag compositions between months during the recruitment season resulted in negligible differences in the accuracy of
Influence of temporal variation in elemental tags on spatial discrimination

Discrimination between Port Phillip Bay and the other nursery areas remained high in adjacent years and months, even though both the MANOVA results and canonical variate plots showed some differences in multielemental tags between years (Fig. 4a) and months (Fig. 4b). Spatial discrimination remained high irrespective of this temporal variation because changes in elemental tags (represented by the $95 \%$ confidence ellipses) did not result in significant changes in the degree of overlap between tags/
Table 4. Pagrus auratus. Classification accuracies from QDFA (quadratic discriminent function analysis) of otolith elemental composition ( $\mathrm{Ba}, \mathrm{Sr}, \mathrm{Mn}$ ) for (a) each year class using the leave-one-out approach, and (b) cross-validation using discriminant functions from 1 year class (the training data set) to classify the other year class treated as of unknown origin

\begin{tabular}{|c|c|c|c|}
\hline \multicolumn{4}{|c|}{ a) Accuracy of predicted group membership (\%) } \\
\hline Sampling period & Year & Others & Port Phillip Bay \\
\hline February & 2000 & 100 & 100 \\
\hline March & 2000 & 100 & 100 \\
\hline Months pooled & 2000 & 100 & 98 \\
\hline February & 2001 & 90 & 90 \\
\hline March & 2001 & 90 & 88 \\
\hline Months pooled & 2001 & 90 & 85 \\
\hline \multicolumn{4}{|c|}{ b) Cross validation accuracy of predicted group membership (\%) } \\
\hline \multicolumn{2}{|c|}{ Year used as training set } & Others & Port Phillip Bay \\
\hline \multicolumn{2}{|l|}{2001} & 98 & 100 \\
\hline \multicolumn{2}{|l|}{2000} & 90 & 83 \\
\hline
\end{tabular}


b

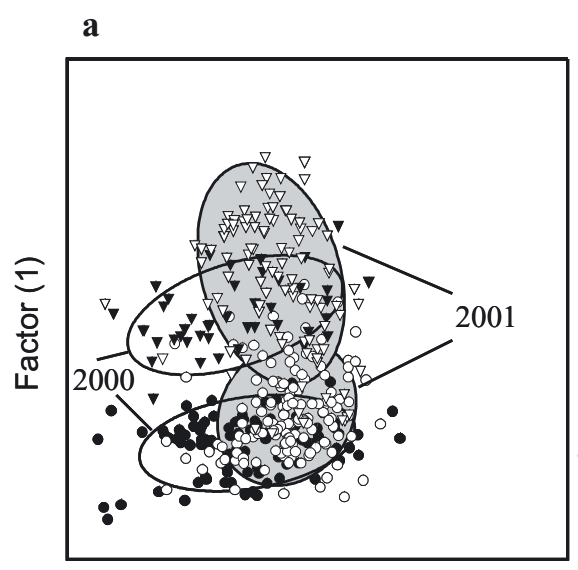

Factor (2)
A Port Phillip Bay 2000

- Other inlets 2000

$\triangle$ Port Phillip Bay 2001 Other inlets 2001

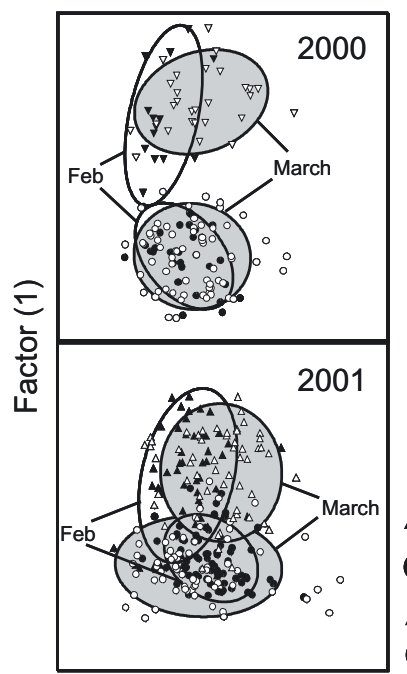

Factor (2)

\section{A Port Phillip Bay February \\ Other inlets February \\ $\Delta$ Port Phillip Bay March O Other inlets March}

Factor (2)

Fig. 4. Pagrus auratus. Canonical variate plots displaying spatial differences in multi-elemental tags of $0+$ otoliths from the Port Phillip Bay and other Victorian nursery areas for (a) 2 adjacent year classes, and (b) 2 adjacent months within 2 adjacent year classes. Ellipses represent $95 \%$ confidence intervals around the data, and data points represent individual fish

discrimination. Variations between adjacent year classes resulted in more significant differences in accuracy of discrimination. Longer-term ( $>5$ yr) among-year-class variation in the elemental signature for Port Phillip Bay was highly significant. This implied that it would be unwise to apply chemical tags identified for one year class of Port Phillip Bay juveniles to the classification of adults from other year classes.

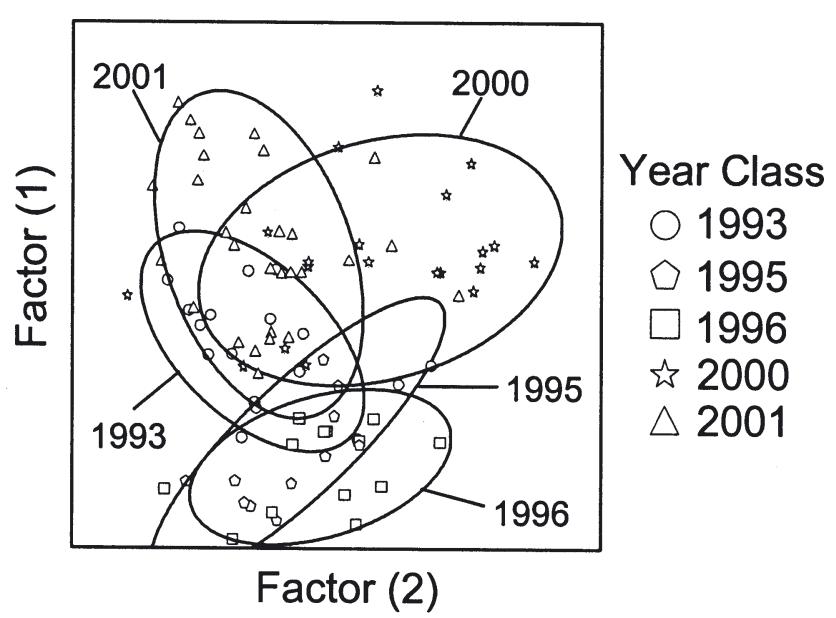

Fig. 5. Pagrus auratus. Canonical variate plot displaying among year class variation in multi-elemental tags of $0+$ otoliths collected at 2 sites within Port Phillip Bay in 5 year classes spread over a 9 yr period. Ellipses represent 95\% confidence intervals around the data, and data points represent individual fish
Previous studies of $0+$ snapper otolith chemistry have demonstrated spatial variation among estuaries along the east Australian coast separated over a wide latitudinal range, with concomitant variations in temperature and rainfall regimes (Gillanders 2002a). Our study involved estuaries and marine embayments along a narrow latitudinal range, and also found considerable spatial variability. We found strong differences in otolith chemistry among areas, with negligible differences in temperature and salinity (see Table 1). For individual elements, spatial variation in Ba and Mn occurred both at small scales $(<10 \mathrm{~km})$ within inlets, and larger scales (>50 km) between inlets, whereas for Sr, spatial variation was minor and observed only at larger scales among inlets. The prior Gillanders (2002a) study also found significant estuary and site-within-estuary variation for Ba and $\mathrm{Mn}$; however, unlike our study, it only found spatial variation in otolith $\mathrm{Sr}$ within individual estuaries, and not between estuaries.

We found temporal variation in otolith chemistry at a range of scales. Temporal variation in otolith multi-elemental tags can have significant implications for their application to retrospective determination of adult origins (Gillanders 2002a). This is particularly the case if temporal differences in otolith tag composition can confound spatial differences (Gillanders 20002a). The results of previous studies (Milton et al. 1997, Patterson et al. 1999, Gillanders \& Kingsford 2000, Rooker et al. 2001a, Gillanders 2002a) have demonstrated the strong potential for differences in otolith chemistry between juveniles from the same areas but different year classes. If this occurs, it is essential that tags used 
to classify adults come from juveniles of the same year class. Temporal variation in otolith chemistry within years has also been demonstrated (Thorrold et al. 1998a, Thorrold \& Shuttleworth 2000, Swearer et al. 2003). Similarly, seasonal and monthly variation in the incorporation of certain elements into adult otoliths has been observed (Kalish 1989, 1991). Thus there is also considerable potential for short-term temporal variation in the composition of otolith chemical tags. Similar to among-year-class variation, fine-scale within yearclass variations in otolith chemistry could have important implications for the way in which otolith tags are identified and applied to the classification of older fish.

In this study, we found differences in otolith chemistry between adjacent year classes that were driven predominantly by 1 element: Sr. However, Sr variation was consistent across all inlets and so did not result in confounding of differences among areas. The strong differences among year classes observed for Port Phillip Bay over longer time scales ( $>5 \mathrm{yr}$ ) were driven predominantly by Ba and $\mathrm{Sr}$ variation. As Ba was crucial to separation of Port Phillip Bay from the other areas, this implied that for confidence in future classification of adults, we would have to use tags characterised from juveniles of the same year classes as the adults. Our results for long-term temporal variation in otolith chemistry are similar to those reported by Campana et al. (2000) for Atlantic cod in the Gulf of St. Lawrence. In their study, whole otolith chemistry was similar between samples collected from the same area in adjacent years, but differed markedly among samples from the same areas compared over intervals of 4 to $13 \mathrm{yr}$. Our study supports the idea that juvenile tags should be characterised on a year-class by year-class basis if they are to be used for determining the origins of older fish.

We also found evidence of variation in otolith chemistry between samples from the same areas taken 1 mo apart. The implications of short-term variation in elemental tags for retrospective analyses of adult origins have perhaps not been adequately addressed by previous studies. Many species of fish have extended recruitment seasons. For example, 0+ snapper can recruit to Victorian inlets over a period of at least 3 to 4 mo (P. A. Hamer unpubl. data). There is considerable scope for environmental variation over such a period, and therefore, juveniles sampled at different times during the recruitment season could have experienced different environmental conditions. This could result in differences in juvenile tag composition depending on when the juveniles were sampled within a recruitment season. If temporal variation at this scale could confound spatial discrimination, the accurate classification of adults based on juvenile tags would require highly accurate matching between the time periods sampled within adult and juvenile otoliths.
In our study, variation in chemical tags between months was driven by variation in Mn that was general across areas, and was of limited importance in spatial discrimination. Variation in $\mathrm{Sr}$ occurred between months at some inlets and, for $\mathrm{Ba}$, variation also occurred between months at some sites within inlets. These changes were relatively minor compared to the overall difference between Port Phillip Bay and the other inlets, and therefore had negligible confounding effect on discrimination in Port Phillip Bay and the other areas. This result is similar to that of Thorrold (1998a), where differences in otolith chemistry of juveniles sampled several months apart were found, yet classification accuracy varied little between the different months. In our case, the accuracy of future adult classification should not be influenced by small temporal differences in either the periods sampled within otoliths of adults from different areas, or between periods sampled within adult otoliths and the juvenile otoliths used to classify them.

While in our study short-term variation in otolith chemistry did not modify tags greatly, the influence of short-term variations in otolith chemistry, or differences among settlement cohorts, on spatial discrimination will never be known a priori. To account for these possibilities, it is wise to develop tags so that they incorporate any short-term temporal variation in otolith chemistry. It is also important that tags are representative of the entire year class of recruits that could eventually contribute to the adult population. We therefore recommend that tags should be based on multiple samples of recruits from the particular year class, and should not be restricted to fish that are all the same size. Otolith tags developed in this way should not require highly accurate temporal matching between sampling of adults and juveniles, thus reducing the risk that the accuracy of classifying adults to juvenile origins could be dependent on the position of the laser sample within the adult otolith.

It is clear from previous studies that a suite of mechanisms including temperature (Radtke et al. 1990, Townsend et al. 1992, Hoff \& Fuiman 1995, Gallahar \& Kingsford 1996, Elsdon \& Gillanders 2002), salinity (Kalish 1990, Secor 1992, Secor et al. 1995, Edmonds et al. 1999, Elsdon \& Gillanders 2002), growth (Sadovy \& Severin 1992, 1994), ontogeny (Kalish 1989, 1991, Fowler et al. 1995), and ambient concentration (Farrell \& Campana 1996, Gallahar \& Kingsford 1996, Thorrold et al. 1998a, Bath et al. 2000, Milton \& Chenery 2001) may be important in influencing element incorporation into otoliths. A detailed understanding of the factors causing variation in elemental incorporation is, however, not essential for use of otolith chemistry as a natural tagging method (Thorrold et al. 1998a), and is not a focus of this study. 
A brief discussion related to Ba is, however, warranted. Otolith Ba levels varied among some sites and inlets in the absences of significant variations in temperature or salinity. Previous studies have demonstrated that ambient concentrations can influence levels of Ba in otoliths (Thorrold et al. 1998a, Bath et al. 2000, Milton \& Chenery 2001). Our preliminary water sample analyses have shown elevated levels of Ba in Port Phillip Bay compared to other inlets and nearby ocean waters (P. A. Hamer unpubl. data). Port Phillip Bay has a highly developed catchment, with 2 large cities, a major port and river, and significant industrial development around its shores. This range of possible sources coupled with the long flushing time of Port Phillip Bay (approximately 1 yr), compared to the other more tidal inlets, offers clear potential for greater build-up of elements such as Ba in its waters.

While spatial variation in otolith elemental composition may not be found in all situations (i.e. Gillanders et al. 2001), this and a growing list of studies suggests that characterisation of nursery-specific chemical tags in otoliths is likely to be possible for many species in many areas. Knowledge of temporal variation in otolith elemental tags will be required at a range of scales to determine how they can be used for studies of connectivity between the juvenile and adult phase. The characterisation of nursery-specific tags in $0+$ snapper otoliths, and their stability during the recruitment period, will allow retrospective analysis of nursery origins of adults and older juveniles from the 2000 and 2001 year classes. This will enable, for the first time, calculations of contributions of the Port Phillip Bay nursery to the adult snapper population both within this Bay and along the Victorian coast. This information will be critical to understanding population dynamics of snapper in Victorian waters.

Acknowledgements. Many thanks go to B. Abbott, S. Brodie, S. Moran, B. McKenzie, R. Jenkins and J. Hindell, who helped with fieldwork, and to J. Tsiros and Y. Lahaye for help with LA-ICP-MS. Fishermen who helped with collections included Eugene Garland and Neville Clark. J. Hindell and 3 anonymous reviewers provided useful comments on this manuscript. This study was funded by a grant awarded to G.P.J. from the Fisheries Research and Development Corporation, Australia (1999/34) and Fisheries Victoria.

\section{LITERATURE CITED}

Anonymous (2002) Fisheries Division, Natural Resources and Environment commercial fish production information bulletin 2002. Marine and Freshwater Resources Institute, Queenscliff

Bath GE, Thorrold SR, Jones CM, Campana SE, McLaren JW, Lam JWH (2000) Strontium and barium uptake in aragonitic otoliths of marine fish. Geochim Cosmochim Acta 64(10):1705-1714
Campana SE (1999) Chemistry and composition of fish otoliths: pathways, mechanisms and applications. Mar Ecol Prog Ser 188:263-297

Campana SE, Gagne JA (1995) Cod stock discrimination using ICPMS elemental assays of otoliths. In: Secor DH, Dean JM, Campana SE (eds) Recent developments in fish otolith research. University of South Carolina Press, Columbia, SC, p 671-691

Campana SE, Thorrold SR (2001) Otoliths, increments, and elements: keys to a comprehensive understanding of fish populations? Can J Fish Aquat Sci 58:30-38

Campana SE, Chouinard GA, Hanson JM, Frechet A, Brattey $\mathrm{J}$ (2000) Otolith elemental fingerprints as biological tracers of fish stocks. Fish Res 46:343-357

Coutin PC, Cashmore S, Sivakumuran KP (2003) Assessment of the snapper fishery in Victoria. Project No 97/127, Final report to Fisheries Research and Development Corporation, Australia. Department of Primary Industries, Queenscliff

Edmonds JS, Moran MJ, Morita M (1989) Trace element analysis of fish sagittae as an aid to stock identification: pink snapper (Chrysophrys auratus) in Western Australian waters. Can J Fish Aquat Sci 46:50-54

Edmonds JS, Caputi N, Morita M (1991) Stock discrimination by trace-element analysis of otoliths of orange roughy (Hoplostethus atlanticus), a deepwater marine teleost. Aust J Mar Freshw Res 42:383-389

Edmonds JS, Lenanton RCJ, Caputi N, Morita M (1992) Trace elements in the otoliths of yellow-eye mullet (Aldrichetta forsteri) as an aid to stock identification. Fish Res 13:39-51

Edmonds JS, Steckis RA, Moran MJ, Caputi N, Morita M (1999) Stock delineation of pink snapper and tailor from Western Australia by analysis of stable isotope and strontium/calcium ratios in otolith carbonate. J Fish Biol 55(2): $243-259$

Elsdon T, Gillanders, BM (2002) Interactive effects of temperature and salinity on otolith chemistry: challenges for determining environmental histories of fish. Can J Fish Aquat Sci 59:1796-1808

Farrell J, Campana SE (1996) Regulation of calcium and strontium deposition on the otoliths of juvenile tilapia, Oreochromis niloticus. Comp Biochem Physiol 115A(2): 103-109

Fowler AJ, Campana SE, Jones CM, Thorrold SR (1995) Experimental assessment of the effect of temperature and salinity on elemental composition of otoliths using laser ablation ICPMS. Can J Fish Aquat Sci 52(7):1431-1441

Gallahar NK, Kingsford, MJ (1996) Factors influencing Sr/Ca ratios in otoliths of Girella elevata: an experimental investigation. J Fish Biol 48:174-186

Gillanders BM (2002a) Temporal and spatial variability in elemental composition of otoliths: implications for determining stock identity and connectivity of populations. Can J Fish Aquat Sci 59:1-11

Gillanders BM (2002b) Connectivity between juvenile and adult fish populations: do adults remain near their recruitment estuaries? Mar Ecol Prog Ser 240:215-223

Gillanders BM, Kingsford MJ (1996) Elements in otoliths may elucidate the contribution of estuarine recruitment to sustaining coastal reef populations of a temperate reef fish. Mar Ecol Prog Ser 141:13-20

Gillanders BM, Kingsford MJ (2000) Elemental fingerprints of otoliths of fish may distinguish estuarine 'nursery' habitats. Mar Ecol Prog Ser 201:273-286

Gillanders BM, Sanchez-Jerez P, Bayle-Sempere JT, RamosEspla A (2001) Trace elements in otoliths of the twobanded bream from a coastal region in the south-west 
Mediterranean: are there differences among locations? J Fish Biol 59:350-363

Gunderson DR, Ellis IE (1986) Development of a plumb staff beam trawl for sampling demersal fauna. Fish Res 4:35-41

Hamer PA, Jenkins GP, Welsford D (1998) Sampling of newlysettled snapper, Pagrus auratus, and identification of preferred habitats in Port Phillip Bay - a pilot study. Project No 96/279, Final report to Fisheries Research and Development Corporation, Australia. Marine and Freshwater Resources Institute, Queenscliff

Hobday DK, Officer RA, Parry GD (1999) Changes to demersal fish communities in Port Phillip Bay, Australia, over two decades; 1970-1991. Mar Freshw Res 50:397-406

Hoff GR, Fuiman LA (1995) Environmentally induced variation in elemental composition of red drum (Sciaenops ocellatus) otoliths. Bull Mar Sci 56(2):578-591

Kalish JM (1989) Otolith microchemistry: validation of the effects of physiology, age and environment on otolith composition. J Exp Mar Biol Ecol 132(3):151-178

Kalish JM (1990) Use of otolith microchemistry to distinguish the progeny of sympatric anadromous and non-anadromus Salmonids. Fish Bull 88:657-666

Kalish JM (1991) Determinants of otolith chemistry: seasonal variations in the composition of blood plasma, endolymph and otoliths of bearded rockcod Pseudophycis barbata. Mar Ecol Prog Ser 74:137-159

Kalish JM, Livingston MN, Schofield KA (1996) Trace elements in the otoliths of New Zealand blue grenadier (Macruronus novaezelandiae) as an aid to stock discrimination. Mar Freshw Res 47:537-542

Lahaye Y, Lambert D, Walters S (1997) Ultraviolet laser sampling and high resolution inductively coupled plasmamass spectrometry of NIST and BCR-2G glass reference materials. Geostandards Newsl 21(2):205-214

Limburg KE, Landergren P, Westin L, Elfman M, Kristiansson $P$ (2001) Flexible modes of anadromy in Baltic sea trout: making the most of marginal spawning streams. J Fish Biol 59:682-695

Ludden JN, Feng R, Gauthier G, Stix J, Shi L, Francis D, Machado N, Wu G (1995) Applications of LAM-ICP-MS analysis of minerals. Can Mineralogy 33:419-434

Milton DA, Chenery SR (2001) Sources of uptake of trace metals in otoliths of juvenile barramundi (Lates calcarifer). J Exp Mar Biol Ecol 264:47-65

Milton DA, Chenery SR, Farmer MJ, Blaber SJM (1997) Identifying the spawning estuaries of the tropical shad, Terubok tenualosa toli, using otolith microchemistry. Mar Ecol Prog Ser 153:283-291

Patterson HM, Thorrold SR, Shenker JM (1999) Analysis of otolith chemistry in Nassau grouper (Epinephalus striatus) from the Bahamas and Belize using solution-based ICPMS. Coral Reefs 18:171-178

Quinn GP, Keough MJ (2002) Experimental design and data analysis for biologists. Cambridge University Press, Cambridge

Radtke RL, Townsend DW, Folsom SD, Morrison MA (1990) Strontium:calcium concentration ratios in otoliths of herring larvae as indicators of environmental histories. Env Biol Fish 27:51-61

Rooker JR, Secor DH, Zdanowicz VS, Tomoyuki I (2001a) Dis-

Editorial responsibility: Otto Kinne (Editor),

Oldendorf/Luhe, Germany crimination of northern bluefin tuna from nursery areas in the Pacific ocean using otolith chemistry. Mar Ecol Prog Ser 218:275-282

Rooker JR, Zdanowicz VS, Secor DH (2001b) Chemistry of tuna otoliths: assessment of base composition and postmortem handling effects. Mar Biol 139:35-43

Sadovy Y, Severin K (1992) Trace elements in biogenic aragonite: correlation of body growth rate and strontium levels in the otoliths of the white grunt, Haemulon plumieri (Pisces: Haemulidae). Bull Mar Sci 50(2):237-257

Sadovy Y, Severin K (1994) Elemental patterns in Red Hind (Epinephelus guttatus) otoliths from Bermuda and Puerto Rico reflect growth rate, not temperature. Can J Fish Aquat Sci 51:133-141

Secor DH (1992) Application of otolith microchemistry analysis to investigate anadromy in Chesapeake Bay striped bass, Morone saxatilis. Fish Bull 90(4):798-806

Secor DH, Rooker JR (2000) Is otolith strontium a useful scalar of life-cycles in estuarine fishes? Fish Res 46:359-371

Secor DH, Henderson-Arzapalo A, Pivvoloi PM (1995) Can otolith microchemistry chart patterns of migration and habitat utilisation in anadromous fishes? J Exp Mar Biol Ecol 192(1):15-33

Swearer SE, Caselle JE, Lea DW, Warner RR (1999) Larval retention and recruitment in an island population of a coral reef fish. Nature 402:799-802

Swearer SE, Forrester GE, Steele MA, Brooks AJ, Lea DW (2003) Spatio-temporal and interspecific variation in otolith trace-elemental fingerprints in a temperate estuarine fish assemblage. Estuar Coast Shelf Sci 56:1111-1123

Thorrold SR, Shuttleworth S (2000) In situ analysis of trace elements and isotope ratios in fish otoliths using laser ablation sector field inductively coupled plasma mass spectrometry. Can J Fish Aquat Sci 57:1232-1242

Thorrold SR, Jones CM, Campana SR, McLaren JW, Lam JWH (1998a) Trace element signatures in otoliths record natal river of juvenile American shad (Alosa sapidissima). Limnol Oceanogr 43(8):1826-1835

Thorrold SR, Jones CM, Swart PK, Targett TE (1998b) Accurate classification of juvenile weakfish, Cynoscion regali, to estuarine nursery areas based on chemical signatures in otoliths. Mar Ecol Prog Ser 173:253-265

Thorrold SR, Latkoczy C, Swart PK, Jones CM (2001) Natal homing in a marine fish metapopulation. Science 291: 297-299

Townsend DW, Radtke RL, Corwin S, Libby DA (1992) Strontium:calcium ratios in juvenile Atlantic herring, Clupea harengus $\mathrm{L}$, otoliths as a function of water temperature. J Exp Mar Biol Ecol 160:131-140

Thresher RE (1999) Elemental composition of otoliths as a stock delineator in fishes. Fish Res 43:165-204

Tzeng WN, Severin KP, Wickstrom H (1997) Use of otolith microchemistry to investigate the environmental history of European eel, Anguilla anguilla. Mar Ecol Prog Ser 149: $73-81$

Wilkinson L, Blank G, Gruber C (1996) Desktop data analysis with SYSTAT. Prentice Hall, Englewood Cliffs, NJ

Yoshinaga J, Atsuko N, Masatoshi M, Edmonds JS (2000) Fish otolith reference material for quality assurance of chemical analyses. Mar Chem 69:91-97

Submitted: October 18, 2002; Accepted: July 29, 2003

Proofs received from author(s): November 3, 2003 